\title{
HALAL COSMETICS REPURCHASE INTENTION: THE ROLE OF MARKETING IN SOCIAL MEDIA
}

\author{
Mohamad Isa Abd Jalil ${ }^{1}$, Suddin Lada ${ }^{2}$, Mohd Ashari Bakri $^{3}$ and Zakiah Hassan ${ }^{4}$ \\ ${ }^{1}$ Universiti Malaysia Sabah, Malaysia, isa@ums.edu.my \\ ${ }^{2}$ Universiti Malaysia Sabah, Malaysia, suddin@ums.edu.my \\ ${ }^{3}$ Universiti Malaysia Sabah, Malaysia, mohd.ashari@ums.edu.my \\ ${ }^{4}$ Universiti Malaysia Sabah, Malaysia, zakiah@ums.edu.my
}

\begin{abstract}
This research aims to study the effects of social media marketing strategies on the repurchase intention among buyers of halal cosmetics manufactured in Malaysia. The study, based on the theory of social media marketing, identifies the nexus, and considers the mediating functions of word-of-mouth brand recognition and electronic word-ofmouth communication (e-WOM). The work takes a holistic view of brand recognition and e-WOM with reference to the two main relations, social media marketing strategy and repurchasing intention. The partial least squares structural equation modelling (PLS-SEM) method was employed and data collected from 300 respondents (followers) via an online questionnaire. The results indicate that there is a significant influence of social media marketing (SMM) on repurchase intention, brand awareness, and e-WOM; the impact is higher on brand awareness, followed by repurchase intention and eWOM. These results demonstrate that efficient brand management of the use of social media platforms will help increase brand awareness among halal cosmetics buyers. When used correctly, SMM may assist the distribution and communication of the most up-to-date information on cosmetic products and brands, resulting in increased awareness and repurchase intent. At the same time, eWOM is a useful tool for their respective followers to disseminate information to followers. The research has important implications for the halal cosmetics sector, as it contributes to the theoretical and management literature on social media marketing strategy.
\end{abstract}

Keywords: Halal, Social media marketing, Brand awareness, e-WOM, Repurchase intention. JEL classification: M31.

Article history:

Received : October 8, 2020

Revised : April 7, 2021

Accepted : June 24, 2021

Available online : November 30, 2021

https://doi.org/10.21098/jimf.v7i4.1379 


\section{INTRODUCTION}

\subsection{Background}

Social media marketing (SMM) refers to the utilisation of web-based applications or social media platforms to communicate with customers to create product awareness, increase sales, and building a competitive brand (Tuten \& Solomon, 2017). This includes distributing exemplary content in companies' social media profiles, listening to and attracting subscribers and followers, analysing results, and conducting social media marketing and promotions (Alsaleh, Elliott, Fu, \& Thakur, 2019; Mangold \& Faulds, 2009). In the modern era, marketers have gained increasing significance in shaping consumer tastes and purchase intentions across social media networks (Kumar \& Mirchandani, 2012), the major social media platforms currently being Facebook, Instagram, Twitter, LinkedIn, Pinterest, YouTube, and Snapchat (Binwani \& Yin Ho, 2019; Clement, 2017). Moreover, social media marketing, also known as "internet marketing" or "e-marketing," employs purpose-built data analytics tools that allow marketers to monitor the effectiveness of their efforts (Cooley \& Parks-Yancy, 2019). With a strong customer relationship, consumer brand awareness is enhanced, and purchase intention and loyalty are consequently increased (Tresna \& Wijaya, 2015; Erdogmus \& Cicek, 2012).

To interact with current and potential customers, social media sites provide two-way interaction, which is the key strategy for firms to develop their product and brand relationships with consumers. Therefore, social media posts (including news, infomation, banners, and sales promotions) have the potential to reach a wide range of customers from all over the world (Cooley \& Parks-Yancy, 2019). Realising this advantage, cosmetic products and brands are vying to increase the number of their followers and subscribers through social media marketing (Binwani \& Yin Ho, 2019); halal cosmetic products/brands are no exception (Suparno, 2020). Such cosmetics are now influencing Asia's beauty care landscape in significant ways in terms of trends, opportunities, and regulations (Lim, 2019). Malaysia, alongside Indonesia and Thailand, is among the three major halal cosmetic markets in South East Asia (Suparno, 2020; Lim, 2019). This development is greatly influenced by the use of social media as effective communication and sales promotions platforms (Doan, 2019; Binwani \& Yin Ho, 2019; Tresna \& Wijaya, 2015). Since halal cosmetic products have unique characteristics compared to normal cosmetics, a major study is needed to accurately describe consumer intentions and their demand characteristics. Nonetheless, little attention has been paid to evaluating the repurchase intention of halal cosmetics with reference to social media marketing - a key strategic factor with a high managerial impact.

In 2017, the market value of halal cosmetics was US\$ 61bn, which is expected to reach US\$ 90bn by 2023 (Trent, 2019). Regrettably, comprehensive investigation into halal cosmetics is notably lacking (Suparno, 2020), particularly with regard to post-purchase behaviour among followers. This relationship is very important, especially if the effects of social media are strongly influenced by brand awareness and e-WOM (Balakrishnan, Dahnil, \& Yi, 2014). Although brand awareness and e-WOM have received much attention from previous researchers (i.e. Suparno, 2020; Balakrishnan et al., 2014), we found very few investigations made on the effects of social media marketing strategy on consumer repurchase intention of halal cosmetics. The question of whether brand awareness and e-WOM have a 
direct or indirect effect on such repurchase intention among followers remains unanswered. Surprisingly, the central question of the majority of previous halal cosmetics studies has mostly focused on factors solely affecting consumer intentions (pre-purchase behaviour) (i.e. Ahmad et al., 2015; Aoun \& Tournois, 2015; Annabi \& Ibidapo-Obe, 2017; Shahid, Ahmed, \& Hasan, 2018), leaving the main argument unaddressed.

\subsection{Objective}

Therefore, to fill the research gaps, the following study objectives are proposed:

1. To examine the relationship between social media marketing strategy (SMM), e-WOM, brand awareness (BA), and repurchase intention (Re-PI).

2. To investigate the mediating roles of e-WOM and brand awareness (BA) in the relationship between social media marketing strategy (SMM) and repurchase intention (Re-PI).

The study makes several significant contributions to the literature. Extending the study of social media marketing by examining the mediating roles of brand awareness and e-WOM can improve our understanding of buyer post-purchase behaviour, particularly with regard to halal cosmetic products. The overall research value will be clear when marketers successfully use the advantages of halal ingredients as their online cosmetics promotional material. Apart from the fact that there is a gap in the body of knowledge, this study was motivated by the wish to assist halal product entrepreneurs worldwide. The study should benefit marketing managers in companies that offer halal products, primarily cosmetic ones, in particular within the changing social media brand management environment. Knowledge and appreciation of halal and haram (this is an Arabic term which means permissible or lawful in Islam) in cosmetic products are vital, and should be considered by all parties, allowing the health and beauty care industry to follow the guidelines set by Islam.

To achieve our goals, the paper is organised as follows. The following sections present in order the literature review, methodology, results and analysis, discussion, and conclusion.

\section{LITERATURE REVIEW AND HYPOTHESIS DEVELOPMENT}

\subsection{Halal Cosmetics and Social Media Marketing}

A narration from Rasulullah s.a.w. asserts that: "Demanding (seeking) that is Halal is obligatory on every Muslim" (narrated by Imam ad-Dailami in Musnad al-Firdaus from Anas r.a.). According to Imam as-Suyuti, this hadith is the rank of Hasan (see al-Jami 'as-Saghier, Hadith no. 5270). The halal-haram law is an important part of Islam's overall legal structure, in which searching and opting for halal products is obligatory for all Muslims (Hashim \& Hashim, 2013). It is also their responsibility to keep away from haram (i.e., Al-Baqarah: 168; Al-Maidah: 88). Halal cosmetics transcend religion because they need rigorous scientific testing to create product that are healthy, reliable, pure, and responsive to the Muslim community's holistic needs (Sugibayashi et al., 2019). Halal compliance should not be seen simply as an oversimplification of a product's inclusion or non-inclusion 
of haram ingredients. They must not contain pig-derived ingredients, predatory animals, reptile carrion, parts of the human body, blood or insects, among others (Suparno, 2020; Sugibayashi et al., 2019). Furthermore, wudhu (ablution)-friendly cosmetics consist of products that are not waterproof and are therefore waterpermeable. The halal logo on halal cosmetics must therefore be recognised as an indicator of quality, purity, cleanliness, and product safety (Hashim \& Hashim, 2013).

Despite the great challenges of the local and international cosmetic markets, the acceptance of cosmetics and beauty care, including halal cosmetics, is surprisingly heavily influenced by online buyers, especially by loyal followers and subscribers (Kumar et al., 2006; Shen \& Bissell, 2013). This is mainly because social media marketing has a positive relationship with strong customer relationships and purchase intentions (Kumar \& Mirchandani, 2012) and brand loyalty (Erdogmus \& Cicek, 2012). The key strategy used in social media marketing is to create messages and content that can be exchanged between individual followers and their families, friends, and colleagues (Alsaleh et al., 2019; Stelzner, 2018). This also encourages customers to create and share their content, such as product reviews or comments (i.e., product/user testimonies). According to Clement (2017), some of the world's leading cosmetics brands are also investing in the strategy, including M.A.C (a US cosmetics brand), which currently has 21.9 million followers, and Anastasia Beverly Hills, with 19.3 million followers. The success of this strategy was also welcomed by several local brands in Malaysia, such as SimplySiti, Pretty Suci, Orkid Cosmetics, SO.LEK, Obsess Cosmetics, and Nurraysa, which now also have thousands of followers (refer to Table 1).

\subsection{Social Media Marketing and Repurchase Intention}

The intention to repurchase products refers to the possibility of the buyer making a re-transaction with the seller (Ou et al., 2014). The seller must then work hard to ensure that the transaction takes place; social media is the best platform for this. It is therefore not surprising that studies on the impact and ability of social media marketing to create the desire or intention to buy have gained widespread attention among practitioners and researchers (e.g., Sugibayashi et al., 2019; Alsaleh et al., 2019; Stelzner, 2018; Ismail, 2017; Shen \& Bissell, 2013; Kumar \& Mirchandani, 2012; Erdogmus \& Cicek, 2012; Kim \& Ko, 2010). Most of their studies have demonstrated that social media marketing has a significant relationship with purchase intention and loyalty. Because repurchase intention is one of the important elements in loyalty (Erdogmus \& Cicek, 2012), it is believed to be strongly influenced by the creative content and sales promotion present in social media marketing. The emotional experience inherent in product attributes (e.g., in halal cosmetics, cleanliness, safety, purity, and quality) will increase the desire to repurchase (Seva, Duh, \& Helander, 2007). Product and brand confidence in the transformation of advertising strategy from traditional methods to social media marketing strategies is not a new phenomenon, making many brands willing to invest in such strategies (Kumar et al., 2006). If social media marketing strategies are successful, consumers are likely to repurchase products and brands (Dehghani \& Tumer, 2015). We therefore hypothesise that 
H1: There is a positive relationship between social media marketing and repurchase intention.

\subsection{Social Media Marketing and Brand Awareness}

In today's world of technology, many companies use social media as one of the platforms to create brand awareness, as well as promote their products and brands (Tritama \& Tarigan, 2016). The fast sharing of product and brand knowledge through content such as banners, posters, videos, and advertisements makes social media an important means of communication (Ho et al., 2015). This notion is emphasised by findings from previous studies (e.g., Alsaleh et al., 2019; Cheah et al., 2019). According to these, to interact with customers, social media sites such as Facebook and Twitter provide the best and fastest way of communication. This two-way interaction is the key for companies to expand their brand relationship with consumers. According to Clement (2017), most international make-up brands (e.g., M.A.C. cosmetics and Anastasia Beverly Hills) nowadays use social media to showcase their brands, and consumers are more likely to buy betterknown ones. However, the question arises as to whether all businesses sell their products effectively and make their brands the focus of their consumers. Thus, it is hypothesised that

\section{H2: There is a positive relationship between social media promotion and brand loyalty.}

\subsection{Social Media Marketing and e-WOM}

Browsing social media sites to find out about products and brands in the market has become current practice. eWOM takes place when users search for information and start commenting or giving personal reviews of products and brands (Ngarmwongnoi, Oliveira, AbedRabbo, \& Mousavi, 2020; Erkan \& Evans, 2016). In reality, it has become a habit for customers to see and analyse the public's views via chat rooms (i.e. user testimonials) before making a buying decision (Hutter, Hautz, Dennhardt, \& Fuller, 2013). Consumers, subscribers, and followers now easily exchange views on brands, products and services with their friends and acquaintances (Gonzales \& Hancock, 2011). With the appearance of different types of online media, eWOM has become an exceptionally widespread and powerful source of information (Wilcox \& Stephen, 2013). Halal cosmetic products and brands are also experiencing this significant change (Suparno, 2020). There is no doubt that social networking platforms such as Facebook (i.e. social networks), Twitter (i.e. micro-blogs), Instagram (i.e. picture sharing), and YouTube (i.e., video sharing), play a major role in transforming the way consumers make buying decisions (Thoumrungroje, 2014). In conclusion, the widespread use of social media has changed the way marketers organise their marketing strategies, especially in promoting and distributing their products. As such, we propose the following hypothesis:

\section{H3: There is a positive relationship between social media promotion and e-WOM.}




\subsection{Brand Awareness and Repurchase Intention}

Repurchase intention is a statement of attitude about how a person will act or make a purchase decision in the future (Aakash \& Aggarwal, 2019; Soderlund \& Ohman, 2003). On the other hand, brand awareness refers to the degree to which customers identify with and remember a brand based on its products or image (Aaker \& Keller, 1990). The relationship between brand awareness and the desire to repurchase can also be clarified by how customers prefer to select brands with a highly recognisable brand identity when making choices; brand awareness is a tool that simplifies purchasing decisions. Many previous debates have prompted other scholars to collaborate on relevant studies, which have had a significant impact on the literature on purchasing intentions with brand recognition $(\mathrm{Wu} \&$ Ho, 2014). Furthermore, this correlation between brand awareness and repurchase intention has been clarified by several previous studies (e.g., Nugraha \& Setyanto, 2018; Jamali \& Khan, 2018; So \& Simamora, 2015). The relationship also received attention from Ho et al., (2015) who clarified that customers infer brand awarenessbased product quality and expect to purchase a brand that is better recognised than those they do not recognise. Moreover, brand awareness can increase the likelihood of considering a brand when making a purchase decision (Binwani \& Yin Ho, 2019; Chakravarti \& Janiszewski, 2003). We therefore hypothesise that

\section{H4: There is a positive relationship between brand awareness and repurchase intention.}

H4a: Brand awareness mediates the relationship between social media promotion and repurchase intention.

\section{5. e-WOM and Repurchase Intention}

With the emergence of online social media, electronic word of mouth (eWOM) has become a significant and powerful source of product information (Tandon, Aakash, \& Aggarwal, 2020; Wilcox \& Stephen, 2013). By sharing information through product reviews and testimonials, it has become a source of motivation for followers to make future purchasing decisions (Erkan \& Evans, 2016). Hutter et al. (2013) also explain that developing marketing through social networking sites has a strong influence on people's purchasing intentions. Nowadays, customers are more likely to ask for feedback from other people before making their own buying decisions. Word of mouth in social media networks therefore has a major impact on buying behaviour (Chen, Fay, \& Wang, 2011). This also has a significant impact on customer purchasing behaviour, from pre-purchase to intentions to repurchase, and brand loyalty (Thoumrungroje, 2014). On social media platforms, followers typically regard peer or colleague feedback as a credible source of information, and so may rely on social media as a way of obtaining information related to their purchases (Chu \& Kim, 2011). The results of a study by Erkan \& Evans (2016) also further clarify through its conceptual model that eWOM users' activity on social media appears to be a factor affecting purchasing intentions. Hence, the following hypotheses are proposed:

H5: There is a positive relationship between e-WOM and repurchase intention. 
H5a: e-WOM mediates the relationship between social media marketing and repurchase intention.

\section{METHODOLOGY}

\subsection{Data}

The unit of analysis in the study is individuals (i.e., followers) who are halal cosmetic users (both male and female), recruited via non-probability quota sampling (a total of 30 followers for each brand). The data collection period covered 3 months between January and March 2020. An online questionnaire (semistructured, using Google Forms) was targeted at and distributed to internet users who had previously bought halal cosmetics online and had read online feedback and reviews obtained from social media (i.e., from websites, Facebook, Instagram, etc.). The followers identified were contacted via email and asked to complete a survey form. The study involved ten local halal cosmetics brands with the highest number of followers. Moreover, these brands had received valid halal certification from JAKIM Malaysia. Malaysia is a country that places great emphasis on halal certification and JAKIM plays an important role in assisting it in its governance and halal certification process (Mohd Safian, 2020). Details of the ten brands are given in Table 1.

Table 1.

Halal Cosmetic Brands

\begin{tabular}{|c|c|c|c|}
\hline No & Brand & Halal Status & $\begin{array}{c}\begin{array}{c}\text { Social Media Platforms \& } \\
\text { (No. of followers) }\end{array} \\
\end{array}$ \\
\hline 1 & SimplySiti & $\begin{array}{l}\text { Halal-certified, wudhu- } \\
\text { friendly, cruelty-free }\end{array}$ & $\begin{array}{c}\text { Website } \\
\text { Facebook } \\
\text { Instagram } \\
(177.1 \mathrm{~K})\end{array}$ \\
\hline 2 & Pretty Suci & $\begin{array}{l}\text { Halal-certified, wudhu- } \\
\text { friendly }\end{array}$ & $\begin{array}{c}\text { Website } \\
\text { Facebook } \\
\text { Instagram } \\
(29.7 \mathrm{~K})\end{array}$ \\
\hline 3 & Orkid Cosmetics & Halal-certified, vegan & $\begin{array}{c}\text { Website } \\
\text { Facebook } \\
\text { Instagram } \\
(5655)\end{array}$ \\
\hline 4 & SO.LEK & $\begin{array}{l}\text { Halal-certified, wudhu- } \\
\text { friendly, cruelty-free }\end{array}$ & $\begin{array}{c}\text { Website } \\
\text { Facebook } \\
\text { Instagram } \\
(28.7 \mathrm{~K})\end{array}$ \\
\hline 5 & Obsess Cosmetics & $\begin{array}{l}\text { Halal-certified, wudhu- } \\
\text { friendly, cruelty-free }\end{array}$ & $\begin{array}{c}\text { Website } \\
\text { Facebook } \\
\text { Instagram } \\
(132.4 \mathrm{~K})\end{array}$ \\
\hline 6 & Nurraysa & $\begin{array}{l}\text { Halal-certified, wudhu- } \\
\text { friendly }\end{array}$ & $\begin{array}{c}\text { Website } \\
\text { Facebook } \\
\text { Instagram } \\
(51 \mathrm{~K})\end{array}$ \\
\hline
\end{tabular}


Table 1.

Halal Cosmetic Brands (Continued)

\begin{tabular}{|c|c|c|c|}
\hline No & Brand & Halal Status & $\begin{array}{l}\text { Social Media Platforms \& } \\
\text { (No. of followers) }\end{array}$ \\
\hline 7 & dUCk Cosmetics & Halal-certified & $\begin{array}{c}\text { Website } \\
\text { Facebook } \\
\text { Instagram } \\
(189.2 \mathrm{~K})\end{array}$ \\
\hline 8 & Sorfina Hal & $\begin{array}{l}\text { Halal-certified, wudhu- } \\
\text { friendly }\end{array}$ & $\begin{array}{c}\text { Facebook } \\
\text { Instagram } \\
(12.7 \mathrm{~K})\end{array}$ \\
\hline 9 & Sugarbelle Cosmetics & $\begin{array}{l}\text { Halal-certified, wudhu- } \\
\text { friendly }\end{array}$ & $\begin{array}{c}\text { Website } \\
\text { Facebook } \\
\text { Instagram } \\
(3378)\end{array}$ \\
\hline 10 & Forest Colour & Halal-certified & $\begin{array}{c}\text { Website } \\
\text { Facebook } \\
\text { Instagram } \\
(3735)\end{array}$ \\
\hline
\end{tabular}

\subsection{Model Development}

The model propose is an extended framework and combination of the theory of reasoned action (TRA) for repurchase intention, brand awareness, eWOM, and social media marketing. A conceptual framework is proposed to model the effect of social media marketing (SMM) (Furqan et al., 2019) on repurchase intention (Suparno, 2020; Lee \& Lee, 2015). In addition, brand awareness (BA) (Tresna \& Wijaya, 2015), and eWOM (Liang et al., 2018) are conceptualized as second-order constructs (mediators). This study identifies these ties and considers the significant relationship and mediating roles of brand awareness and eWOM.

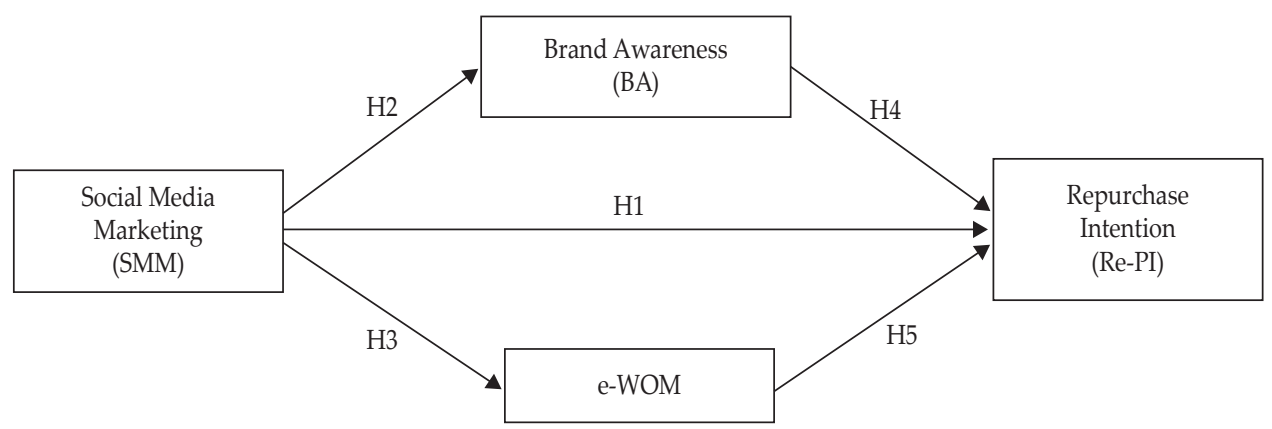

Figure 1.

Proposed Theoretical Framework of the Study

This study involves four latent variables: the exogenous variables of social media marketing and repurchase intention, and the mediating endogenous ones of brand awareness and eWOM. Figure 1 shows the proposed theoretical framework 
of the study. The reliability and validity of the constructs were established, and all 16 items were measured using a seven-point Likert scale $(1=$ strongly disagree, $2=$ disagree, $3=$ somewhat disagree, $4=$ neither agree nor disagree, $5=$ somewhat agree $6=$ agree $7=$ strongly agree). These items are more accurate and easier to use of a respondent's true evaluation. In light of all these advantages, even when compared to higher-order items, seven items appear to be the best solution for questionnaires, such as those used in usability evaluations (Finstad, 2010). Table 2 lists the measurement items used in the study.

Table 2.

List of Measurement Items

\begin{tabular}{|c|c|c|c|}
\hline Construct & Description/Code & $\begin{array}{l}\text { Total } \\
\text { Items }\end{array}$ & $\begin{array}{l}\text { Source (adapted } \\
\text { from) }\end{array}$ \\
\hline $\begin{array}{l}\text { Social media } \\
\text { marketing } \\
(\text { SMM) }\end{array}$ & $\begin{array}{l}\text { I can easily recognize halal cosmetic products/ } \\
\text { brands by their profile picture on the company's } \\
\text { social media page (SMM1). } \\
\text { - Halal cosmetic products/brands share informative } \\
\text { captions on the social media page (SMM2). } \\
\text { - I often get answers to my queries from halal } \\
\text { cosmetic product/brand social media pages } \\
\text { (SMM3). } \\
\text { - Halal cosmetic products/brands have a large } \\
\text { number of followers on social media (SMM4). }\end{array}$ & 4 & $\begin{array}{l}\text { Furqan Khan and } \\
\text { Jan (2019) }\end{array}$ \\
\hline $\begin{array}{l}\text { Brand awareness } \\
\text { (BA) }\end{array}$ & $\begin{array}{l}\text { - I am aware of halal cosmetic products/brands } \\
\text { (BA1) } \\
\text { - I can recognize halal cosmetic product/brand } \\
\text { logos in comparison with those of other products/ } \\
\text { brands (BA2) } \\
\text { - I know what the physical appearance of halal } \\
\text { cosmetic products/brands looks like (BA3) } \\
\text { - When I think of cosmetics, halal cosmetic } \\
\text { products/brands are the first I think of (BA4) } \\
\text { - When I want to buy cosmetics, halal cosmetic } \\
\text { products/brands are the first I consider (BA5). }\end{array}$ & 5 & $\begin{array}{c}\text { Tresna and Wijaya } \\
\text { (2015) }\end{array}$ \\
\hline $\begin{array}{l}\text { e-WOM } \\
\text { (eWOM) }\end{array}$ & $\begin{array}{l}\text { - I often read other followers' online reviews to find } \\
\text { out whether halal cosmetic products/brands make } \\
\text { a good impression on others (eWOM1). } \\
\text { - To make sure I choose the right halal cosmetic } \\
\text { products/brands, I often read online reviews } \\
\text { (eWOM2). } \\
\text { - I often consult other followers' online reviews to } \\
\text { help choose a good halal cosmetic product/brand } \\
\text { (eWOM3). } \\
\text { - I always share the latest sales promotion } \\
\text { information with other followers (eWOM4). }\end{array}$ & 4 & Liang et al. (2018) \\
\hline $\begin{array}{l}\text { Repurchase } \\
\text { intention } \\
\text { (Re-PI) }\end{array}$ & $\begin{array}{l}\text { - I have the intention to repurchase halal cosmetic } \\
\text { products online (Re-PI1). } \\
\text { - I intend to use online shopping websites to } \\
\text { repurchase halal cosmetics (Re-PI2). } \\
\text { - I aml likely to repurchase cosmetic products from } \\
\text { cosmetic online stores soon (Re-PI3). } \\
\end{array}$ & 3 & $\begin{array}{l}\text { Suparno (2020); } \\
\text { Lee and Lee (2015) }\end{array}$ \\
\hline
\end{tabular}




\subsection{Method}

The partial least squares - structural equation modelling (PLS-SEM) method was employed on a sample of 300 online customers (i.e., followers). This was appropriate since this is an exploratory study that aims to maximise the value of $\mathrm{R}$ square, while predicting the relationship between social media marketing, brand awareness, e-Wom, and repurchase intention. A two-step process was used to assess the research model: 1) model measurement assessment and 2) structural model evaluation (Astrachan, Patel, \& Wanzenried, 2014). Validation of the model is vital to ensure empirical work standards for both measurement and structural models. This study used PLS-SEM because its objective was to predict key target constructs or identify key driver constructs (Hair, Ringle, \& Sarstedt, 2011). Using this method, the researchers were able to visually study the relationships that occur between the variables of interest in order to prioritise resources to serve customers better. The fact that unobservable, hard-to-measure latent variables can be used in SEM makes it ideal for tackling business research problems. Since the selected cosmetic brands are local Malaysian brand manufacturers, the selected respondents are amongst the local followers.

For the mediation effect, the Sobel test calculation was used to explain whether there was a significant indirect effect of the independent variable on the dependent variable through the mediator. This calculator returns the Sobel test statistic (Sobel, 1982), and both one-tailed and two-tailed probability values; the Sobel test equation is:

$$
z \text {-value }=a^{*} b / S Q R T\left(b^{2 *} s a^{2}+a^{2 *} b^{2}\right)
$$

\section{RESULTS AND ANALYSIS}

\subsection{Results}

\subsubsection{Descriptive Statistics of the Sample}

With reference to Table 3, it was found that female followers dominated the sample, constituting $93 \%$ compared to male followers, who only made-up $7 \%$ of the total respondents surveyed. In addition, followers aged between 21 and 30 recorded the highest percentage of $56.3 \%$, followed by the age group of 20 and below, at $22 \%$. The age group of 51 and over was the smallest group involved in this study. When it comes to the profession, the working group recorded the highest number of participants, $48 \%$, followed by students and those who were self-employed, at $25 \%$ and $16 \%$ respectively. The majority of respondents are from the income group between RM3000-6000 and represented 40.7\% of the sample, with the highest income being RM9001 and above, representing only $2.3 \%$. The study also examined how often the respondents used cosmetics, finding that on average they did so every day (55\%). However, $12.7 \%$ of the followers only used cosmetics on special occasions. 
Table 3.

Demographics and Cosmetic Usage Experience

\begin{tabular}{lcc}
\hline Demographics & Frequency & \% \\
\hline Gender & 21 & 7.0 \\
Male & 279 & 93.0 \\
Female & & \\
\hline Age & 66 & 22.0 \\
20 and below & 169 & 56.3 \\
$21-30$ & 33 & 11.0 \\
$31-40$ & 29 & 9.7 \\
$41-50$ & 3 & 1.0 \\
51 and above & & \\
\hline Profession & 75 & 25.0 \\
Student & 144 & 48.0 \\
Employed & 48 & 16.0 \\
Self-Employed & 30 & 10.0 \\
Unemployed & 3 & 1.0 \\
Retired & & \\
\hline Income & 108 & 36.0 \\
No fixed income & 51 & 17.0 \\
RM1000 - 3000 & 122 & 40.7 \\
RM3001 - 6000 & 12 & 4.0 \\
RM6001 - 9000 & 7 & 2.3 \\
RM9001 and above & & \\
\hline How often do you use cosmetics? & 165 & 55.0 \\
Every day & 67 & 22.3 \\
3-4 days a week & 30 & 10.0 \\
1-2 days a week & 38 & 12.7 \\
On special occasions only & &
\end{tabular}

\subsection{Measurement Model}

The measurement model relates the measured variables to the latent ones. Therefore, it asses the reliability of individual items by examining the loadings and cross-loadings of the indicators of each construct. However, during the EFA analysis, the BA6 (i.e. Halal cosmetic products/brands are often the choice of my friends and I) and eWOM5 (i.e. I frequently gather information from followers' online reviews before I choose to buy halal cosmetic products/brands) items were found to have low loading values and had to be dropped. Table 4 lists the reliability measures of the individual items. All the reliability measures are higher than 0.8, exceeded the recommended level of 0.7 (Barclay et al., 1995), indicating adequate individual item trustworthiness. In other words, more variance is shared between constructs and their measurements than errors. 
Table 4.

Loading and Cross-Loading of Measures

\begin{tabular}{lcccc}
\hline Construct/Item & BA & Re-PI & SMM & eWOM \\
\hline BA1 & $\mathbf{0 . 9 8 8}$ & 0.440 & 0.356 & 0.408 \\
BA2 & $\mathbf{0 . 9 8 6}$ & 0.449 & 0.352 & 0.435 \\
BA3 & $\mathbf{0 . 9 9 1}$ & 0.445 & 0.350 & 0.442 \\
BA4 & $\mathbf{0 . 9 8 7}$ & 0.443 & 0.343 & 0.438 \\
BA5 & $\mathbf{0 . 9 8}$ & 0.440 & 0.347 & 0.422 \\
\hline Re-PI1 & 0.431 & $\mathbf{0 . 9 2 7}$ & 0.412 & 0.242 \\
Re-PI2 & 0.381 & $\mathbf{0 . 9 1 5}$ & 0.397 & 0.234 \\
Re-PI3 & 0.439 & $\mathbf{0 . 9 4 9}$ & 0.369 & 0.261 \\
\hline SMM1 & 0.330 & 0.354 & $\mathbf{0 . 8 6 9}$ & 0.127 \\
SMM2 & 0.321 & 0.374 & $\mathbf{0 . 8 7 8}$ & 0.103 \\
SMM3 & 0.236 & 0.339 & $\mathbf{0 . 8 2 0}$ & 0.107 \\
SMM4 & 0.311 & 0.372 & $\mathbf{0 . 8 4 3}$ & 0.147 \\
\hline WOM1 & 0.404 & 0.171 & 0.111 & 0.852 \\
WOM2 & 0.410 & 0.204 & 0.145 & 0.906 \\
WOM3 & 0.396 & 0.263 & 0.132 & 0.914 \\
WOM4 & 0.362 & 0.284 & 0.122 & 0.914 \\
WOM5 & 0.376 & 0.284 & 0.122 & 0.914 \\
\hline NOS:BA & &
\end{tabular}

Notes: BA=brand awareness; Re-PI=repurchase intention; SMM=social media marketing; eWOM=electronic word of mouth. Bold font represents significance at the 0.05 level

Based on Fornell and Lacker's (1981) suggestion, we measured internal consistency by the levels of square root of the AVE for each construct should be greater than the correlation involving the constructs. Table 5 shows the reliability of the internal consistency. All the reliability measures were higher than the recommended level of 0.7 (Nunnally, 1978), at between 0.8755 and 0.9941 , indicating adequate internal consistency. Furthermore, we assessed discriminant validity by using average variance extracted (AVE) (Fornell \& Lacker, 1981). This captures the average variance shared between the construct and its size. The measure should be greater than the variance shared between a particular construct and the other constructs in the model (i.e., the quadratic correlation between the two constructs) (Barclay et al., 1995).

Table 5.

Internal Consistencies, Convergent Validity

\begin{tabular}{lcccc}
\hline Constructs & AVE & $\begin{array}{c}\text { Composite } \\
\text { Reliability }\end{array}$ & R Square & $\begin{array}{c}\text { Cronbach's } \\
\text { Alpha }\end{array}$ \\
\hline BA & 0.977 & 0.995 & $\mathbf{0 . 3 5 4}$ & 0.994 \\
Re-PI & 0.866 & 0.951 & $\mathbf{0 . 6 7 1}$ & 0.923 \\
SMM & 0.728 & 0.914 & - & 0.875 \\
eWOM & 0.805 & 0.942 & $\mathbf{0 . 2 0 4}$ & 0.920 \\
\hline
\end{tabular}

For adequate discriminant validity, the diagonal elements in the matrix should be much larger than the diagonal elements in the appropriate rows and columns (Barclay et al., 1995). AVE is generated automatically using the bootstrap technique by PLS-Graph. Table 6 below lists the correlation matrices for constructs. 
The diagonal element in the "correlation construction" (in bold) is the square root of AVE.

Table 6.

Discriminant Validity and Correlation of Constructs

\begin{tabular}{lcccc}
\hline Construct & BA & Re-PI & SMMs & eWOM \\
\hline BA & 0.977 & & & \\
Re-PI & 0.449 & $\mathbf{0 . 8 6 6}$ & & \\
SMM & 0.354 & 0.422 & 0.728 & \\
eWOM & 0.434 & 0.264 & 0.142 & $\mathbf{0 . 8 0 5}$ \\
\hline
\end{tabular}

The diagonal element in table 5 is the correlation between the constructs. In this study, discriminant validity assessment did not reveal a problem, as the AVE for each construct was greater than its correlation with all the other constructs in the model (if the diagonal element is greater than the appropriate diagonal outer element). The validity of the discrimination is further confirmed when no item should be loaded higher on the other construct (Barclay et al., 1995).

\subsection{Structural Model}

A structural model demonstrates the causal relationships between constructs. This includes estimates of the path coefficients indicating the strengths of the hypothesized relationship, and the value of $\mathrm{R}^{2}$ which evaluates the model's predictive power (Henseler et al., 2009). Together, the coefficients of the $\mathrm{R}^{2}$ and the direction (i.e. the loadings and significance) demonstrate how well the data support the hypothesised model (Chin, 1998; Gil-Garcia, 2008). Based on Hair et al.'s (2011) recommendation, $\mathrm{R}^{2}$ values of $0.75,0.50$, or 0.25 can be described as substantial, moderate, or weak, respectively. In our case, the results show (refer to Table 5) that the $\mathrm{R}^{2}$ values for the three constructs were 0.671 (for Re-PI), 0.546 (for BA), and 0.204 (for eWOM) respectively. Therefore, the model has a moderate predictive power for repurchase intention and brand awareness, but weak predictive power for eWOM.

Table 7 and Figure 2 show the test results of the PLS-Graph hypothesis structure model. Based on the results obtained, it was found that H1 (SMM -> RePI), H2 (SMM -> BA), H3 (SMM -> eWOM), and H4 (BA -> Re-PI) are significantly supported. However, H5 (eWOM -> Re-PI) was not supported. These results indicate that there is a significant relationship between social media marketing (SMM) on repurchase intention (Re-PI), brand awareness, and e-WOM. Moreover, the impact of social media marketing is higher on brand awareness, followed by repurchase intention and eWOM. 
Table 7.

Path Coefficients

\begin{tabular}{|c|c|c|c|c|c|}
\hline \multicolumn{6}{|c|}{ Path Coefficient } \\
\hline & $\beta$ & $\begin{array}{c}\text { Standard } \\
\text { Error }\end{array}$ & T-Statistic & Hypothesis & Result \\
\hline SMM -> Re-PI & 0.628 & 0.136 & 4.623 & H1 & Supported \\
\hline $\mathrm{SMM}->\mathrm{BA}$ & 0.748 & 0.078 & 9.481 & $\mathrm{H} 2$ & Supported \\
\hline SMM -> eWOM & 0.674 & 0.170 & 3.964 & $\mathrm{H} 3$ & Supported \\
\hline BA $->$ Re-PI & 0.452 & 0.130 & 3.459 & $\mathrm{H} 4$ & Supported \\
\hline eWOM -> Re-PI & -0.051 & 0.127 & 0.399 & H5 & $\begin{array}{c}\text { Not- } \\
\text { Supported }\end{array}$ \\
\hline \multicolumn{6}{|c|}{ Mediation effects of BA and eWOM (Sobel Test) } \\
\hline & $\begin{array}{c}\text { Test } \\
\text { Statistics }\end{array}$ & $\begin{array}{c}\text { Standard } \\
\text { Error }\end{array}$ & p-value & & \\
\hline SMM -> BA-> Re-PI & 3.250 & 0.104 & 0.001 & $\mathrm{H} 4 \mathrm{a}$ & Supported \\
\hline SMM-> eWOM -> Re-PI & 0.397 & 0.086 & 0.691 & H5a & $\begin{array}{c}\text { Not- } \\
\text { Supported }\end{array}$ \\
\hline
\end{tabular}

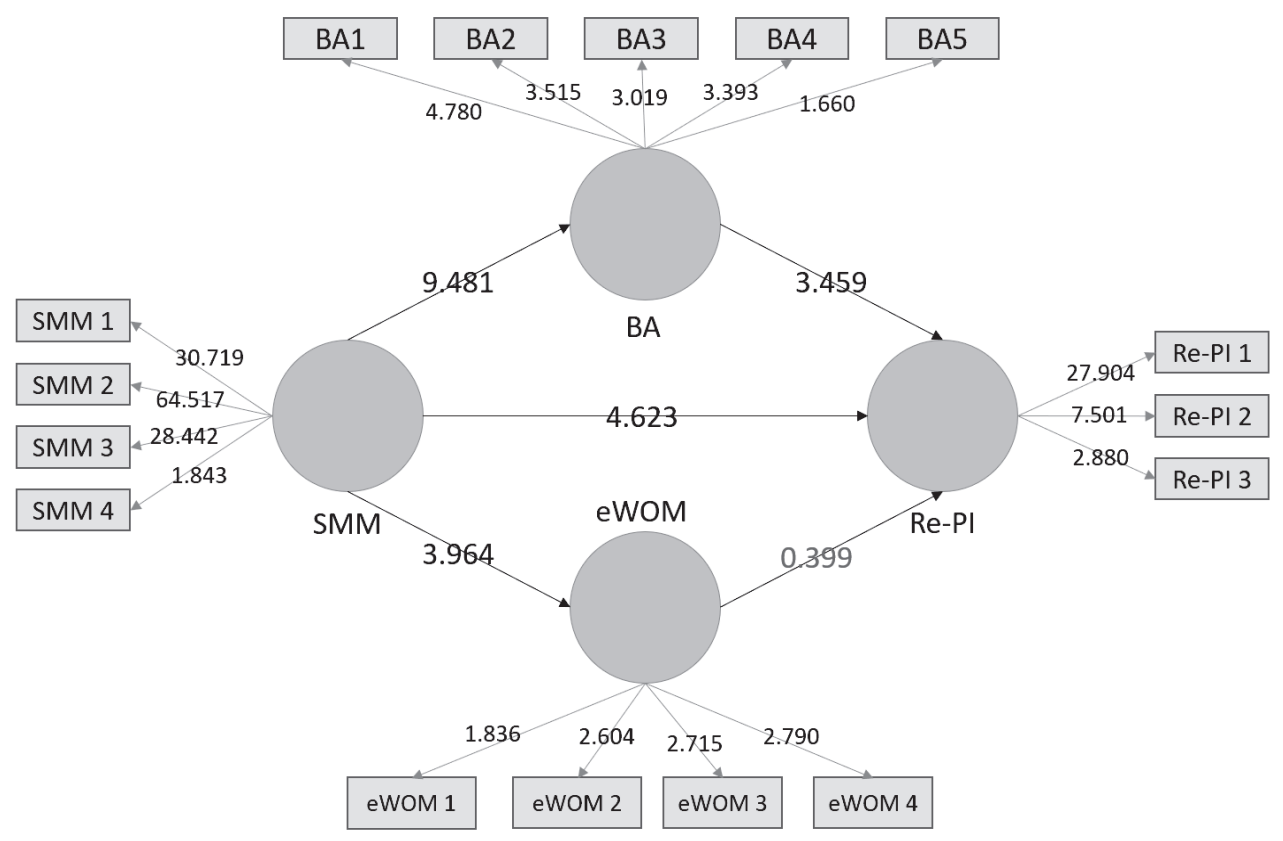

Figure 2.

Research Model Results

The findings show support for $\mathrm{H} 4 \mathrm{a}$, but do not endorse H5a. In other words, brand awareness affects the direct relationship between social media marketing and the intention to repurchase. Moreover, the results of the Sobel test on brand awareness $(\beta=3.250$, $p$-value $=0.001)$ explains that this mediation relationship is partial. Therefore, it can be concluded that repurchase intention can be strengthened by increasing the level of brand awareness among followers. At the same time, the 
findings of the study indicate that H5a was not accepted and that in the context of halal cosmetics, the influence of eWOM does not affect the relationship between social media marketing and repurchase intention.

\subsection{Analysis}

The study has succeeded in achieving its objectives based on the analysis and the results obtained. The results which meet the model measurement and structural model requirements also clarify the validity and reliability of the analysis. As explained above, the results mean that $\mathrm{H} 1, \mathrm{H} 2, \mathrm{H} 3$, and $\mathrm{H} 4$ are supported, but $\mathrm{H} 5$ is not, and that social media marketing (SMM) has a significant relationship with brand awareness, eWOM, and repurchase intention. Similar results were obtained for the relationship between brand awareness and repurchase intention, but not for the relationship between eWOM and repurchase intention.

The results show that social media marketing has a positive effect on repurchase intention, which is consistent with a previous study such as (Ho \& Chung, 2020). In other words, SMM is a good predictor of repurchase intention. The perfect combination of brand management of halal cosmetics and SMM strategy will help increase the desire among buyers to repurchase. The findings of this study also demonstrate that SMM is a tool that supports electronic commerce and viral marketing, which helps build network relationships and social confidence among cosmetics buyers. The results of this study are also supported by several previous researchers such as Hutter, Hautz, Dennhardt, \& Füller (2013) and Dabbous \& Barakat (2020), who strengthen the argument that brand awareness can be improved by an effective social media strategy. The results prove that efficient brand management of the use of social media platforms will help increase brand awareness among halal cosmetics buyers, especially their followers. In addition, the results of the study also strengthen the evidence that social media marketing has a direct impact on eWOM among followers. The planned use of SMM with the right approach to the involvement of followers will help disseminate and share the latest information and information on manufacturers' products and brands. eWOM is an effective channel for the distribution of information by companies' respective followers.

The findings of the study also confirm that BA has a significant relationship with repurchase intention. Consumers will intend to buy if a brand is familiar to them. In other words, if a product has high brand awareness, it will have a higher chance of repurchase. Therefore, halal cosmetic manufacturers should take advantage of this. The findings of the study also reinforce the notion that wellknown brands will have higher purchasing intention than less well-known ones. However, it was found that eWOM will not necessarily affect repurchase intention. This may be heavily influenced by eWOM's credibility and quality, which also indirectly influences repurchase intentions.

The following is a further discussion of the study objectives which were achieved. 
Objective 1: To examine the relationship between Social media marketing, repurchase intention, brand awareness, and eWOM.

The results show that social media marketing has a positive effect on repurchase intention, which is consistent with previous studies (i.e., Alsaleh et al., 2019; Binwani \& Yin Ho, 2019; Erkan \& Evans, 2016; Thoumrungroje, 2014; Hutter et al., 2013). Therefore, the results imply that social media marketing leads to increased repurchase intention. These findings are believed to be strongly influenced by creative content, advertising and sales promotion, updated news and information, and ongoing notifications through various social media platforms. For example, during Eid al-Fitr (the religious holiday is celebrated by Muslims celebration), Simplysiti products and brands have held the red jewellery contest (2018) contest; Golden Raya Contest (2018); Buy \& Win (2017); and Tutorial Challenge 2016, are using social media as a platform. The fact is that if social media marketing campaigns are successful, then customers are likely to repurchase products and brands (Dehghani \& Tumer, 2015).

Touching on the relationship between social media marketing and brand awareness, the promotional approach through social media taken by most manufacturers of halal cosmetics products today indirectly supports the findings of the study. As explained above, an effective social media marketing strategy will increase the level of brand awareness among followers, especially in relation to the issues of halal and haram, which are closely related to the manufacture and use of sacred cosmetics. The special features and requirements of halal cosmetics (i.e. cleanliness, safety, purity, and quality) have become key ingredients of awareness (Hashim \& Hashim, 2013). In conclusion, brand awareness will increase the probability that a brand is considered when a buying decision is made (Binwani \& Yin Ho, 2019; Chakravarti \& Janiszewski, 2003). Knowledge services and halal cosmetics campaigns should be expanded to raise market awareness.

The relationship between social media marketing and $e W O M$ is very clear, and the findings of the study are supported by several previous researchers (Suparno, 2020; Thoumrungroje, 2014; Hutter et al., 2013; Wilcox \& Stephen, 2013). Consumers today are wise in evaluating before buying, and eWOM has opened up the space and opportunity to gather enough information through product reviews and testimonies before purchase decisions are made. Halal cosmetic brands see social media as a forum for promoting their products, through which eWOM can connect with a larger audience. The findings of this study also reinforce the arguments of Clement (2017), Thoumrungroje (2014), and Suparno (2020), who claim that even world-famous cosmetic products and brands use social media and eWOM applications to interact with their followers. In addition, halal and e-WOM labels have had a strong and important impact on the decision of consumers to repurchase Safi skincare products (Gunari, 2019). In conclusion, local halal cosmetic manufacturers should take advantage of the versatility of social media marketing and the proven benefits of eWOM.

\section{Objective 2: The mediating roles of brand awareness and e-WOM.}

Based on the findings related to hypothesis H4a (mediation effects), it was found that there is support for brand awareness as a mediator. Although it is only partial mediation, it can be concluded that repurchase intention can be strengthened 
by increasing the level of brand awareness. This partial mediation decision is supported by Binwani and Yin Ho (2019), who stress that increasing the level of brand awareness will also help increase purchase interest. What is more convincing, is that social media marketing can give an advantage to products and brands over their competitors. This is supported by Cover (2020), who explains that when consumers follow a brand on social media it will gain an advantage of $84 \%$ compared to its competitors, while remaining relevant in the hearts of followers. The right brand awareness strategy depends on how well-known the brand is. Therefore, manufacturers of halal cosmetic products and brands are advised to integrate all their activities on social media in order to increase brand awareness and further increase repurchase intention directly.

Based on the findings, eWOM was found to have no impact on the relationship between social media marketing and the intention to repurchase, meaning that it did not serve as a mediator. A customer might not consider eWOM as critical in establishing their intention to repurchase. Users are accustomed to the comments and criticisms provided; it is entirely up to them to believe these or not. Looking at these insignificant results and their relationship with halal cosmetics, the conclusion that can be drawn is that eWOM, which was originally very effective in information sharing, can become a source of negative influence very quickly, which can ultimately affect purchase intentions. Halal cosmetic manufacturers are advised to be prepared to receive criticism and bad reviews from netizens. This is very important, because the social media user network is very strong in the online community, and can affect the purchasing decision-making process in the future.

\section{CONCLUSION AND RECOMMENDATIONS}

\subsection{Conclusion}

As an Islamic country in Southeast Asia, surrounded by a number of other Muslim-majority countries, Malaysia has taken the initiative in developing halal products (e.g.., Halal Hub Malaysia), including support for the halal cosmeticsbased industry. This initiative is in line with the true recommendation of Prophet Muhammad S.A.W, that "Searching for halal is obligatory to every Muslim". In addition, it will be a new attraction for Muslim and non-Muslim customers to go shopping in Malaysia. Recognising the fact that competitive pressures are occurring within and outside the country, this has forced manufacturers to expand their marketing strategies to social media, which has proven its effectiveness. It is evident that social media marketing successfully influences the desire to repurchase. Moreover, serious emphasis should be placed on efforts to increase brand awareness among followers so that a company's products and brands remain attached to the hearts of consumers.

\subsection{Recommendations}

Some future research proposals can be made so that the findings of this study can be improved. First, study should be made of the negative effects of social media on the reputation and image of companies that face negative comments and reviews from netizens. This is very important, because such comments are 
difficult to control, which will eventually affect the daily operations of companies. Second, studies should also be made of the effectiveness of social media marketing, specifically with reference to the Honeycomb model (Smith, 2007). This model is useful because each social media platform has different goals and objectives (i.e., identity, presence, conversation, sharing, relationship, groups, and reputation) and each one needs to be measured separately. Third, the study focused only on selected local halal cosmetic brands, while a variety of other such brands also exist on the market. It is recommended that future studies take into account local and international products and brands, for example Amara Halal cosmetics, Sampure, Sorfina Hal, Zahara, and Mersi as local halal cosmetic brands, and Kat von D, The Balm, Wet $\mathrm{n}$ Wild, Cover FX, and Color Pop as international brands. As a final recommendation, a special study on the relationship between gender and halal cosmetics" could be conducted, as the modern world perceives the direct involvement of consumers of cosmetics and healthcare products to be no longer limited to gender disparities.

\section{REFERENCES}

Aakash, A., \& Aggarwal, A. G. (2019). Role of EWOM, product satisfaction, and website quality on customer repurchase intention strategy and superior performance of micro and small businesses in volatile economies. IGI Global, Hershey, 144-168. https://doi.org/10.4018/978-1-5225-7888-8.ch010.

Aaker, D. A, \& Keller, K. L. (1990). Consumer evaluations of brand extensions. Journal of Marketing, 54(1), 27-41.

Alsaleh, D. A., Elliott, M. T., Fu, F. Q., \& Thakur, R. (2019). Cross-cultural differences in the adoption of social media. Journal of Research in Interactive Marketing, 13(1), 119-140.

Ahmad, A. N., Rahman, A., \& Rahman, S. A. (2015), Assessing knowledge and religiosity on consumer behavior towards halal food and cosmetic products. International Journal of Social Science and Humanity, 5(1), 10-14.

Annabi, A. C., \& Ibidapo Obe, O. O. (2017). Halal certification organization in the United Kingdom: An exploration of halal cosmetic certification. Journal of Islamic Marketing, 8(1), 107-126.

Aoun, I., \& Tournois, L. (2015). Building holistic brands: An exploratory study of halal cosmetics. Journal of Islamic Marketing, 6(1), 109-132.

Astrachan, C. B., Patel, V. K., \& Wanzenried, G. (2014). A comparative study of CBSEM and PLS-SEM for theory development in family firm research. Journal of Family Business Strategy, 5(1), 116-128.

Balakrishnan, B. K. P. D., Dahnil, M. I., \& Yi, W. J. (2014). The impact of social media marketing medium toward purchase intention and brand loyalty among generation Y. Procedia - Social and Behavioral Sciences, 148(25 August 2014), 177-185

Barclay, D., Higgins, C., \& Thompson, R. (1995). The partial least squares (PLS) approach to causal modeling: personal computer adoption and use as an illustration. Technology Studies, 2(2), 285-323.

Binwani, K. J., \& Yin Ho, J. S. (2019). Effects of social media on cosmetic brands. Journal of Marketing Advances and Practices (JMAP), 1(2), 1-10. 
Chakravarti, A., \& Janiszewski, C. (2003). The influence of macro-level motives on consideration of composition sets in novel purchase situations. Journal of Consumer Research, 30(2), 244-258.

Cheah, J. H., Ting, H., Cham, T. H., \& Memon, M. A. (2019). The effect of selfie promotion and celebrity-endorsed advertisement on decision-making processes: A model comparison. Internet Research, 29(3), 552-577.

Chen, Y., Fay, S., \& Wang, Q. (2011) The role of marketing in social media: How online consumer reviews evolve. Journal of Interactive Marketing, 25(2), 85-94.

Chin, W. W. (1998), The partial least squares approach to structural equation modeling, in Marcoulides, G.A. (Ed.), Modern methods for business research. Mahwah, NJ: Lawrence Erlbaum Associates, pp. 295-336.

Chu S-C., \& Kim, Y. (2011) Determinants of consumer engagement in electronic word-of-mouth (eWOM) in social networking sites. International Journal of Advertising, 30(1), 47-75.

Clement, J. (2017) Leading beauty brands ranked by number of Instagram followers as of May 2019 (in millions). Statista - The Statistics Portal. Available from: https://www.statista.com/statistics/536991/leading-beauty-brands-instagramfollowers/ [Accessed 20 Aug. 2020].

Cooley, D., \& Parks-Yancy, R. (2019). The effect of social media on perceived information credibility and decision making. Journal of Internet Commerce, 18(3), 249-269.

Cover, L. (2020). 8 stats that demonstrate how social drives business growth. Published Online at https://sproutsocial.com/insights/social-data-for-businessgrowth/. May 05, 2020.

Dabbous, A., \& Barakat, K. A. (2020). Bridging the online offline gap: Assessing the impact of brands' social network content quality on brand awareness and purchase intention. Journal of Retailing and Consumer Services, 53(2020), 101966.

Dehghani, M., \& Tumer, M. (2015). A research on effectiveness of Facebook advertising on enhancing purchase intention of consumers. Computers in Human Behavior, 49, 597-600.

Doan, E. Z. (2019). Size of the cosmetics market in the Asia Pacific region from 2015 to 2020 (in billion U.S. dollars). Statista - The Statistics Portal. Available from: https://www.statista.com/statistics/550547/cosmetic-market-size-asia-pacific/ [Accessed 20 Aug. 2020].

Erdogmus, I. E., \& Cicek, M. (2012). The impact of social media marketing on brand loyalty. Procedia-Social and Behavioral Sciences, 58, 1353-1360.

Erkan I., \& Evans, C. (2016) The influence of eWOM in social media on consumers' purchase intentions: An extended approach to information adoption. Computers in Human Behavior, 61(August 2016), 47-55.

Finstad, K. (2010). Response interpolation and scale sensitivity: Evidence against 5-point scales. Journal of Usability Studies, 5(3), 104-110.

Fornell, C., \& Lacker, D.F. (1981), Evaluation structural equation models with unobserved variables and measurement error. Journal of Marketing Research, 18 (1), 39-50.

Furqan Khan, M., \& Jan, A. (2019). A measure of social media marketing: Scale development and validation. Jindal Journal of Business Research, 1-11. https:// www.researchgate.net/publication/333718942 June 2019. 
Gil-Garcia, J.R. (2008), Using partial least squares in digital government research, in Garson, G.D. and Khosrow-Pour, M. (Eds), Handbook of Research on Public Information Technology, Hershey: Idea Group, 239-53.

Gonzales, A. L., \& Hancock, J. T. (2011). Mirror, mirror on my Facebook wall: Effects of Facebook exposure on self-esteem. Cyberpsychology, Behavior, and Social Networking, 14(1), 79-83.

Gunari, K. T. P. (2019). Pengaruh label halal dan electronic word of mouth (e-wom) terhadap minat beli ulang konsumen pada produk skincare safi [The effect of halal labels and electronic-word of mouth (e-wom) on consumers repurchase interest in safi skincare products]. Undergraduate Thesis, Bandung: Universitas Pendidikan Indonesia. http://repository.upi.edu/38448/.

Hair, J. F., Ringle, C. M. \& Sarstedt, M. (2011). PLS-SEM: Indeed a silver bullet. The Journal of Marketing Theory and Practice, 19(2), 139-152.

Hashim, P., \& Mat Hashim, D. (2013). A review of cosmetic and personal care products: Halal perspective and detection of ingredient. Pertanika Journal Science Technology, 21(2), 281-292.

Henseler J., Hubona G., \& Ray P. A., Using PLS path modeling in new technology research: Updated guidelines. Industrial Management $\mathcal{E}$ Data Systems, 116(1), 2-20.

Ho, C. H, Chiu, K. H, Chen, H., \& Papazafeiropoulou, A. (2015). Can internet blogs be used as an effective advertising tool? The role of the blog type and brand awareness. Journal of Enterprise Information Management, 28(3), 346- 362.

Ho, M. H.-W., \& Chung, H. F. L. (2020). Customer engagement, customer equity and repurchase intention in mobile apps. Journal of Business Research, 121(2020), 13-21.

Hutter, K., Hautz, J., Dennhardt, S., \& Füller, J. (2013) The impact of user interactions in social media on brand awareness and purchase intention: The case of MINI on Facebook. Journal of Product \& Brand Management, 22(5/6), 342-351.

Ismail, A. R. (2017). The influence of perceived social media marketing activities on brand loyalty: The mediation effect of brand and value consciousness. Asia Pacific Journal of Marketing and Logistics, 29(1), 129-144.

Jamali, M., \& Khan, R. (2018). The impact of consumer interaction on social media on brand awareness and purchase intention! Case study on Samsung. Journal of Marketing and Logistic, 1 August 2018, 114-129. http://jml.kasbit.edu.pk/ Current\%20Issue/Page\%20114\%20-129.pdf

Kim, A. J., \& Ko, E. (2010). Impacts of luxury fashion brand's social media marketing on customer relationship and purchase intention. Journal of Global Fashion Marketing, 1(3), 164-171.

Kumar, S., Massie, C., \& Dumonceaux, M. D. (2006). Comparative innovative business strategies of major players in the cosmetic industry. Industrial Management \& Data Systems, 106(3), 285-306.

Kumar, V., \& Mirchandani, R. (2012). Increasing the ROI of social media marketing. MIT Sloan Management Review, 54(1), 55-61.

Lada, S., Suki, N. M., \& Sidin, S. M. D. (2014). The roles of brand experience in forming loyalty intention. Labuan e-Journal of Muamalat and Society, 8(2014), 3949. 
Lee, J., \& Lee, J. (2015). How purchase intention consummates purchase behaviour: The stochastic nature of product valuation in electronic commerce. Behaviour and Information Technology, 34(1), 57-68.

Liang, L. J., Choi, H. S. C \& Joppe, M. (2018). Understanding repurchase intention of Airbnb consumers: Perceived authenticity, electronic word-of-mouth, and price sensitivity. Journal of Travel E Tourism Marketing, 35(1), 73-89.

Lim, A. (2019). Halal beauty: How the thriving segment is reshaping Asia's cosmetics landscape. Retrieved online on 25 Aug. 2020 at https://www. cosmeticsdesign-asia.com/Article/2019/06/24/Halal-beauty-How-the-thrivingsegment isreshaping-Asia-s-cosmetics. 24 Jun 2019.

Mangold, W.G., \& Faulds, D.J. (2009). Social media: The new hybrid element of the promotion mix. Business Horizons, 52(4), 357-365.

Mohd Safian, Y. H. (2020). Halal governance in Malaysia companies. Journal of Fatwa Management and Research, 6(2), 40-52.

Ngarmwongnoi, C., Oliveira, J.S., AbedRabbo, M., \& Mousavi, S. (2020). The implications of eWOM adoption on the customer journey. Journal of Consumer Marketing, 37(7), 749-759.

Nugraha, A., \& Setyanto, RP (2018). The effects of vlogger credibility as marketing media on brand awareness to customer purchase intention. Journal of Research in Management, 1(2), 1-10.

Nunnally, J. (1978), Psychometric theory. New York, NY: McGraw-Hill.

Ou, C. X., Pavlou P. A., \& Davison R. (2014). Swift guanxi in online marketplaces: The role of computer-mediated communication technologies. MIS Quarterly, 38(1), 209-230.

Seva, R. R., Duh, H. B., \& Helander, M. G. (2007). The marketing implications of affective product design. Applied Ergonomics, 38(6), 723-731.

Shahid, S., Ahmed, F., \& Hasan, U. (2018). A qualitative investigation into consumption of halal cosmetic products: The evidence from India. Journal of Islamic Marketing, 9(3), 484-503.

Shen, B., \& Bissell, K. (2013). Social media, social me: A content analysis of beauty companies' use of Facebook in marketing and branding. Journal of Promotion Management, 19(5), 629-651.

Smith, G. (2007). nForm, from Social Software Building Blocks: http://nform.com/ blog/2007/04/social-softwarebuilding-blocks/ In Tresna, L., \& Wijaya, J. C. (2015). The impact of social media towards brand equity: An empirical study of Mall X. iBuss Management, 3(2), 37-48.

Stelzner, M. (2018). 2018 social media marketing industry report. Social Media Examiner, 1-52. Retrieved from https://www.socialmediaexaminer.com/

Soderlund, M., \& Ohman, N. (2003). Behavioral intentions in satisfaction research revised. Journal of Consumer Satisfaction, Dissatisfaction, and Complaining Behavior, 16(2003), 53-66.

So, IG, \& Simamora, BH (2015). The influence of website quality, brand awareness, and perceived quality products on purchase intention of online store video games. In International Conference on Technology, Informatics, Management (2015) Engineering \& Environment (TIME-E) (pp. 31-33). IEEE. https://doi.org/10.1109/ TIME-E.2015.7389743. 
Sobel, M. E. (1982). Asymptotic intervals for indirect effects in structural equation models. In S. Leinhart (Ed.), Sociological methodology (pp. 290-312). San Francisco: Jossey-Bass.

Sugibayashi, K., Yusuf, E., Todo, H., Dahlizar, S., Sakdiset, P., Arce, F. Jr., \& See, G. L. (2019). Halal cosmetics: A review on ingredients, production, and testing methods. Cosmetics, 6(3), 37-53.

Suparno, C. (2020). Online purchase intention of halal cosmetics: S-O-R framework application. Journal of Islamic Marketing, 12(9), 1665-1681.

Tandon, A., Aakash, A., \& Aggarwal, A. G. (2020). Impact of EWOM, website quality, and product satisfaction on customer satisfaction and repurchase intention: Moderating role of shipping and handling. International Journal of System Assurance Engineering and Management, 11(Supplement 2), 349-356.

Thoumrungroje, A. (2014). The influence of social media intensity and e-wom on conspicuous consumption. Procedia - Social and Behavioral Sciences, 148 (2014), 7-15.

Trent, N. (2019). Halal Cosmetics Market 2018-Industry Analysis, Share, Growth, Sales, Trends, Supply, Forecast to 2025. Reuters. Available online: https:// www.reuters.com/brandfeatures/venture-capital/article?id=52417 (accessed on 21 May 2020).

Tresna, L., \& Wijaya, J. C. (2015). The impact of social media towards brand equity: An empirical study of Mall X. iBuss Management, 3(2), 37-48.

Tritama, H. B., \& Tarigan, R. E. (2016). The Effect of Social Media on the Brand Awareness of a Product of a Company. CommIT Journal, 10(1), 9-14.

Tuten, T. L., \& Solomon, M. R. (2017). Social media marketing. Newbury Park, CA: Sage Publications.

Wilcox, K., \& Stephen, A. T. (2013). Are close friends the enemy? Online social networks, self-esteem, and self-control. Journal of Consumer Research, 40(1), 90103.

Wu, S.I., \& Ho, L. P. (2014). The influence of perceived innovation and brand awareness on purchase intention of innovation product - An example of iPhone. International Journal of Innovation and Technology Management, 11(4), 1450026. 